\title{
MPR DALAM SISTEM KETATANEGARAAN INDONESIA (STUDI KOMPARATIF ANTARA SEBELUM DAN SESUDAH PERUBAHAN UUD 1945)
}

\author{
Oleh:
}

I Wayan Eka Santika', I Gede Sujana²

E-mail: ekasantika56@gmail.com¹, dalungsujana@gmail.com²

Dosen FKIP, Universitas Dwijendra

\begin{abstract}
The purpose of this research was to determine the People's Consultative Assembly in the Indonesian constitutional system. This research was a type of library research which is descriptive analytic through a qualitative approach that is based on comparative studies. The results of this research indicated that there are fundamental differences between the People's Consultative Assembly before and after the amendment to the 1945 Constitution. The differences included (1) the change in the position of the People's Consultative Assembly from the highest state institution to a state institution that is equal to other state institutions, (2) changes in the membership structure of the People's Consultative Assembly from those previously consisted of House of Representatives, Group Envoys and Regional Representatives, then became members of the House of Representatives and Regional Representative Board members, (3) the policy to appoint People's Consultative Assembly members was replaced by an election system, (4) the People's Consultative Assembly no longer stipulates the Broad Outlines of the Nation's Direction along with filling the position of President through participation the people directly in the election, (5) limitation of the People's Consultative Assembly's authority in amending the 1945 Constitution, (6) the inauguration of the President and / or Vice President in normal and abnormal conditions, (8) the authority of the People's Consultative Assembly to dismiss the President and / or Vice President must be through a forum previlegiatum.
\end{abstract}

Keywords: People's Consultative Assembly, State Administration, Amendment to the 1945 Constitution.

Tujuan penelitian ini adalah untuk mengetahui MPR dalam sistem ketatanegaraan Indonesia. Penelitian ini temasuk jenis penelitian pustaka yang bersifat deskriptif analitik melalui pendekatan kualitatif yang bertumpu pada studi komparatif. Hasil penelitian ini menunjukan, bahwa terdapat perbedaan mendasar antara MPR sebelum dan sudah Perubahan UUD 1945. Perbedaannya antara lain (1) perubahan kedudukan MPR dari lembaga tertinggi negara menjadi lembaga negara yang sederajat dengan lembaga negara lainnya, (2) perubahan struktur keanggotaan MPR dari yang sebelumnya terdiri dari DPR, Utusan-Utusan Golongan dan Utusan Daerah, kemudian menjadi anggota DPR dan anggota DPD, (3) dihapuskannya kebijakan pengangkatan anggota MPR yang diganti dengan sistem pemilu, (4) MPR tidak lagi menetapkan GBHN seiring dengan pengisian jabatan Presiden melalui partisipasi langsung rakyat dalam pemilu, (5) adanya pembatasan kewenangan MPR dalam mengubah UUD 1945, (6) pelantikan Presiden dan/atau Wakil Presiden dalam kondisi normal dan tidak normal, (8) kewenangan MPR untuk 
MPR DALAM SISTEM KETATANEGARAAN INDONESIA (STUDI KOMPARATIF

ANTARA SEBELUM DAN SESUDAH PERUBAHAN UUD 1945)

(Santika \& Sujana, 91-100)

memberhentikan Presiden dan/atau Wakil Presiden haruslah melalui forum previlegiatum.

Kata Kunci : MPR, Ketatanegaraan, Perubahan UUD 1945.

\section{PENDAHULUAN}

Dengan runtuhnya dinasti Orde Baru melalui gelombang reformasi, UUD 1945 yang dulunya diberhalakan pada akhirnya berhasil diubah. Siapa sangka angan-angan untuk mengubah UUD 1945 yang pada masa Orde Baru dianggap sebagai sebuah mitos tidak terpecahkan, kemudian dengan gagah perkasa didobrak dan dibongkar kaum reformis.

Dilakukannya Perubahan UUD 1945 oleh MPR pada gilirannya berimplikasi luas terhadap sistem ketatanegaraan Indonesia (Rohmat, 2016). Harus diakui, bahwa terdapat perbedaan yang mendasar antara kedudukan, tugas, fungsi, dan kewenangan lembaga negara sebelum dan sesudah Perubahan UUD 1945. Hal itu memang sesuai dengan maksud dan tujuan awal Perubahan UUD 1945, yaitu menata kembali kelembagaan negara dengan jalan mereposisi, mendefinisi, dan mengkaji ulang kedudukan, tugas, fungsi, dan kewenangannya. Salah satu lembaga negara yang mengalami pergeseran signifikan akibat UUD 1945 diubah adalah MPR.

Banyak ahli hukum dan politik yang mencoba melihat, mengkaji, dan membahas, serta menyampaikan opini ataupun pandangan objektif terhadap MPR. Mengingat setalah UUD 1945 diubah, kedudukan, tugas, fungsi, dan kewenangan MPR berubah drastis. Tetapi sayangnya, pembahasan yang dilakukan sering kali hanya terpaku, terkungkung, dan terjebak pada norma yang tercantum dalam teks UUD 1945 (Asmara, 2015). Pembahasan MPR dalam sistem ketatanegaraan kerap kali dilakukan tanpa memperhatikan adanya dinamika kenegaraan Indonesia yang membidani, mengiringi, dan melatar belakangi lahirnya norma tersebut. Tidak ayal makna konstitusional yang hendak dihantarkan penulis belum sepenuhnya mampu diterima, diresapi, dan dipahami pembaca (Santika, 2020).

Oleh sebab itu guna memperoleh dan menyuguhkan pemahaman yang holistik, komperhensif, dan integratif, terhadap usaha pengkajian MPR pasca Perubahan UUD 1945 haruslah diawali dan berangkat dua perspektif berbeda. Aspek historis melalui studi komparatif atau perbandingan sebelum UUD 1945 tidak boleh dilupakan. Sebaliknya eksistensi MPR UUD 1945 sebelum perubahan harus dijadikan titik tolak dalam mengkajinya. Berdasarkan latar belakang persoalan tersebut, judul yang diangkat dalam penelitian ini adalah MPR Dalam Sistem Ketatanegaraan Indonesia (Studi Komparatif Antara Sebelum Dan Sesudah Perubahan UUD 1945).

\section{METODE}

Penelitian ini temasuk jenis penelitian pustaka (library research), karena data yang dibutuhkan maupun dikumpulkan bersumber dari bahan pustaka, sehingga bisa disebut sebagai penelitian dokumenter (documenter research). Penelitian ini bersifat deskriptif analitik, karena memaparkan dan menyelusuri kedudukan, tugas, fungsi dan kewenangan MPR melalui studi 
komparatif antara sebelum dan sudah Perubahan UUD 1945 kemudian dianalisa untuk mendapat pemahaman yang benar. Teknik pengumpulan data yang digunakan adalah metode dokumentasi, yaitu dengan mengoleksi atau mengumpulkan bahan hukum yang berhubungan dengan ketentuan konstitusi yang secara normatif mengatur MPR dalam UUD 1945.

Dalam menganalisis data peneliti menggunakan pendekatan kualitatif, yang bertumpu pada studi komparatif, yaitu dengan mengkomparasikan segisegi yang berlainan dari kedudukan, tugas, fungsi, dan kewenangan MPR antara sebelum dan sesudah Perubahan UUD 1945.

\section{PEMBAHASAN}

Sebelum UUD 1945 diubah, MPR adalah lembaga negara super power yang menjadi lokus kedaulatan rakyat Indonesia. Secara historis Pasal 1 Ayat (2) UUD 1945 sebelum perubahan menyatakan, bahwa "Kedaulatan berada di tangan rakyat, dan dilakukan sepenuhnya oleh Majelis Permusyawaratan Rakyat". Hal itu diperkuat dalam Penjelasan Pasal 1 Ayat (2) UUD 1945. Dengan berpedoman pada Pasal 1 Ayat (2) UUD 1945 berikut Penjelasannya dapat dikatakan, bahwa MPR merupakan lembaga tertinggi Negara (Ubaidillah, 2017), yang secara tidak langsung menempatkan lembaga negara lain berada di bawahnya.

Dengan kedudukan MPR yang superior itu, mustahil prinsip checks and balances dapat diterapkan secara optimal dalam sistem ketatanegaraan Indonesia. Artinya posisi MPR sebagai lembaga negara yang memegang dan melaksanakan kedaulatan rakyat tidak mungkin ditandingi atau diimbangi oleh lembaga negara lainnya (Asshiddiqie, 2011).
Dalam tataran praktis-empirisnya, bahwa distorsi tersebut sesungguhnya tidak hanya terjadi secara tekstual dalam naskah UUD 1945, tetapi juga menjalar pada ranah implementasinya di lapangan. Monopoli MPR atas kedaulatan rakyat berdasarkan pesan legal konstitusional UUD 1945 adalah penyelewengan nyata terhadap prinsip-prinsip negara hukum Indonesia yang menganut sistem politik demokrasi. Kedaulatan rakyat yang dilaksanakan sepenuhnya oleh MPR justru telah mereduksi paham kedaulatan rakyat menjadi paham kedaulatan negara, suatu paham yang hanya lazim dianut oleh negara yang masih menerapkan totalitarian atau otoritarian (Sekretariat Jenderal MPR RI, 2011).

Penyerahan kedaulatan rakyat melalui jalur konstitusi merupakan satu-satunya rute konstitusional yang ditempuh MPR untuk merengkuh kembali kepercayaan rakyat Indonesia terhadap UUD 1945. Perubahan Pasal 1 Ayat (2) UUD 1945 menandakan terjadinya perubahan fundamental dalam sistem ketatanegaraan Indonesia, yaitu dari sistem yang sebelumnya vertical-hierarkis dengan prinsip supremasi MPR menjadi sistem yang horizontal-fungsional dengan prinsip-prinsip saling mengimbangi dan saling mengawasi antar lembaga negara. Pasca amandemen UUD 1945, kedudukan MPR sejajar dengan lembaga-lembaga negara lain (Widayati, Absori, dan Aidul, 2014).

$$
\text { Perubahan Pasal } 1 \text { Ayat (2) UUD }
$$

1945 mengakibatkan kedudukan antara lembaga negara adalah sejajar. Perbedaannya hanya didasarkan pada tugas, fungsi, dan kewenangannya masing-masing. Pasalnya berdasarkan UUD 1945 yang diamandemen tentang eksistensi, fungsi, tugas, dan wewenang MPR, ia bukan lagi 
lembaga wakil rakyat yang tinggi dan tertinggi. Dan bukan juga sebagai lembaga yang sangat berkuasa seperti sebelumnya (Isra, 2010).

Reformasi konstitusi melalui Perubahan UUD 1945 sebanyak empat kali dalam satu rangkaian perubahan, faktanya tidak hanya secara radikal mereposisi kedudukan MPR. Karena Perubahan UUD 1945 juga menyasar susunan keanggotaan MPR. Susunan keanggotaan MPR dirombak secara struktural dengan menghapus eksistensi Utusan Daerah dan Utusan Golongan. Sebelum diubah, Pasal 2 Ayat (1) UUD 1945 berbunyi: "Majelis Permusyawaratan Perwakilan Rakyat terdiri atas anggota-anggota Dewan Perwakilan Rakyat. Ditambah dengan utusanutusan dari daerah-daerah dan golongan-golongan, menurut aturan yang ditetapkan dengan undangundang". Penjelasan Pasal 2 Ayat (1) UUD 1945 menafsirkan utusan golongan, yaitu "Maksudnya ialah supaya seluruh rakyat, seluruh golongan, seluruh daerah akan mempunyai wakil dalam Majelis, sehingga Majelis itu akan betul-betul dapat dianggap sebagai penjelamaan rakyat. Yang disebut "golongangolongan" ialah badan-badan seperti koperasi, serikat pekerja dan lain-lain badan kolektif. Aturan demikian memang sesuai dengan aliran zaman. Berhubung dengan anjuran mengadakan sistem koperasi dalam ekonomi, maka ayat ini mengingat akan adanya golongan-golongan dalam badan-badan ekonomi". Jika diperhatikan Pasal 2 Ayat (1) UUD 1945 sebelum perubahan, susunan keanggotaan MPR lebih lanjut, UUD 1945 mengatribusikan pengaturannya melalui undangundang. Sedangkan kekuasaan riil membentuk undang-undang, baik secara yuridis maupun poliitis sesungguhnya berada di bawah kendali penuh Presiden. Praksis dengan besarnya kekuasaan itu, telah menjadikan Presiden sebagai penafsir tunggal atas kehendak UUD 1945. Terbukti secara historis-empiris undang-undang hasil kinerja lembaga legislatif yang memformalisasi susunan keanggotaan MPR justru mereduksi posisi MPR sebagai lembaga tertinggi negara.

Menurut Oktavia contoh faktual yang menguatkan terjadinya pelanggaran konstitusional melalui penafsiran lembaga pembentuk undang-undang, yaitu intepretasi parsial terhadap Penjelasan Pasal 2 Ayat (1) UUD 1945, khususnya mengenai kata golongan-golongan (Oktava, 2017). Melalui penafsiran sepihak, Presiden dan DPR telah mengaburkan makna hakiki Penjelasan Pasal 2 Ayat (1) UUD 1945 dengan memasukan militer sebagai salah golongan. Pemaknaan seperti itu, jelas berseberangan dengan original inten yang membidani Pasal 2 Ayat (1) UUD 1945 beserta Penjelasannya yang secara eksplisit menegaskan, bahwa yang dimaksud golongan-golongan, yaitu badanbadan koperasi, serikat, pekerja, dan lain-lain badan kolektif. Tampak gamblang DPR dan Presiden memanipulasi arti kata "lain-lain badan kolektif" sebagai celah politik untuk melegalisir kedudukan militer di MPR.

Berbeda tajam dengan ketentuan sebelumnya, bahwa Pasal 2 Ayat (1) UUD 1945 pasca perubahan, mengatur susunan keanggotaan MPR terdiri atas anggota DPR dan anggota DPD. Pasal 2 Ayat (1) UUD 1945 hasil perubahan menyatakan, bahwa "Majelis Permusyawaratan Rakyat terdiri atas anggota Dewan Perwakilan Rakyat dan Anggota Dewan 
Perwakilan Daerah yang dipilih melalui pemilihan umum dan diatur lebih lanjut dengan undang-undang". Perubahan Pasal 2 Ayat (1) UUD 1945 lebih dimaksudkan untuk meneguhkan paham kedaulatan rakyat melalui pemilu demokratis.

Dengan dipilihnya semua anggota melalui pemilu, otomatis meningkatkan kadar legitimasi MPR sebagai salah satu lembaga yang pembentukannya melalui proses demokrasi. Penekanan pemilu sebagai syarat imperatif dalam mengisi keanggotaan MPR adalah koheren dengan prinsip-prinsip yang berlaku di negara-negara demokrasi. Prinsip itu berlaku pula dalam pemilu di Indonesia, dimana rakyat dilibatkan partisipasinya secara langsung untuk memilih wakil-wakilnya yang duduk dan berjuang di MPR. Mekanisme politik pengisian keanggotaan MPR melalui pemilu ialah sesuai dengan prinsip UUD 1945 yang memposisikan rakyat sebagai sumber kedaulatan negara (Sekretariat Jenderal MPR RI, 2011).

Ditentukannya keanggotaan MPR harus dipilih melalui pemilu merupakan ekspresi sikap politik rakyat Indonesia untuk memperkuat keberadaan lembaga tersebut. Fakta historis telah membuktikan, bahwa MPR di bawah naungan UUD 1945 sebelum perubahan begitu lemah dan tidak berdaya dalam menerapkan checks and balances (Yani, 2018). Kegagalan MPR dalam memainkan perannya itu, sangat erat kaitannya dengan dibudayakannya praktek pengangkatan keanggotaaan MPR oleh Presiden. Pengangkatan Utusan Daerah dan Utusan Golongan dalam jumlah yang begitu fantastis pada masa Orde Baru adalah bukti faktual yang mengindikasikan terjadinya tindakan inkonstitusional oleh lembaga legislatif terhadap pengisian keanggotaan MPR. Tidak heran bila MPR justru "tunduk" kepada Presiden selaku eksekutif (Rannie, 2017).

Di samping susunan keanggotaan dan kedudukannya, UUD 1945 juga mengatur tugas dan wewenang MPR. Ketentuan tersebut akan dibahas kritis melalui metode komparatif. Selain dalam UUD 1945, fungsi, tugas, dan wewenang MPR diatur pula melalui Pasal 4 UU No. 27 Tahun 2009.

Wewenang MPR mengubah dan menetapkan UUD 1945 adalah kajian pertama dalam artikel ini. Mengingat Pasal 3 Ayat (1) UUD 1945 merupakan urutan teratas yang memformalisasi wewenang MPR. Sebelum mengalami perubahan, Pasal 3 Ayat (1) UUD 1945 berbunyi "Majelis Permusyawaratan Rakyat menetapkan Undang-Undang Dasar dan garis-garis besar haluan negara". Sedangkan setelah Pasal 3 Ayat (1) UUD 1945 diubah, bunyinya menjadi "Majelis Permusyawaratan Rakyat berwenang mengubah dan menetapkan UndangUndang Dasar".

Pada Pasal 3 ayat (1) UUD 1945 sebelum perubahan, di dalamnya memuat kata "menetapkan". Kemudian yang menjadi pokok permasalahan di sini, apakah kata "menetapkan" sama maknanya dengan kata "mengubah"? Diawal reformasi muncul argumentasi, bahwa kata "menetapkan" dalam Pasal 3 Ayat (1) UUD 1945 berarti MPR hanya berwenang mengukuhkan UUD 1945. Mengingat sebelum disahkan PPKI yang dikuatkan kembali dengan Pidato Ir. Soekarno selaku Ketuanya, bahwa UUD 1945 masih bersifat intrim. Bila pengertian demikian disematkan, maka MPR tidak memiliki kewenangan untuk mengubah UUD 1945. Artinya MPR hanya boleh mengukuhkan atau menetapkan UUD 
1945 yang dianggap bersifat sementara (intrim), sehingga menjadi permanen.

Tetapi pengertian di atas tampak keliru berhubung Dekrit Presiden 5 Juli 1959 adalah sebuah keputusan yuridis yang menetapkan sifat permanen UUD 1945. Untuk memahami kewenangan MPR secara holistik dalam mengubah UUD 1945 haruslah juga memperhatikan Pasal 37 UUD 1945 yang secara expressis verbis menyatakan MPR sebagai lembaga yang bukan saja berwenang menetapkan, tetapi juga berhak mengubah UUD 1945. Bab XVI pada Pasal 37 UUD 1945 sebelum perubahan mengatur wewenang MPR dalam mengubah UUD 1945. Pasal 37 UUD 1945 sebelum diubah terdiri atas dua ayat.

Setelah UUD 1945 diubah, MPR semakin mengukuhkan/memantapkan dirinya sebagai lembaga negara yang memonopoli kewenangan mengubah UUD 1945. Sebab berdasarkan Pasal 3 Ayat (1) UUD 1945 pasca perubahan, MPR telah memperjelas kedudukannya untuk mengubah dan menetapkan UUD 1945. Ketentuan tersebut adalah sikap tegas MPR dalam merespon pro kontra (polemik) yang sempat muncul terkait wewenangnya untuk mengubah UUD1945.

Dengan Pasal 37 UUD 1945 sebelum diubah MPR dapat saja melalui kewenangannya melakukan perubahan atau penggantian total terhadap UUD 1945 dengan UUD baru sama sekali. Apalagi Pasal 37 UUD 1945 sebelum diubah tidak merestriksi kewenangan MPR dalam mengubah UUD 1945. Artinya dahulu jika MPR berkehendak, maka bisa saja mengganti UUD 1945 secara keseluruhan (Santika, 2021). Tetapi setelah melihat dan mencermati Pasal
37 UUD 1945 hasil perubahan, maka MPR tidak lagi berwenang untuk mengubah konstitusi dalam satu paket.

Karena Pasal 37 UUD 1945 menutup ruang perubahan dilakukan satu paket (keseluruhan) undangundang dasar. Jangankan UUD 1945 diubah secara keseluruhan, sebab untuk mendorong perubahan pasalperpasal saja sangat sulit dilakukan. Ketentuan ini adalah konsekuensi logis dari kesepakatan dasar sebelum UUD 1945 diubah pada tahun 1999, bahwa addendum adalah metode Perubahan UUD 1945.

Sebab hanya untuk mengusulkan perubahan pasal-pasal UUD 1945 agar dapat diagendakan dalam sidang MPR, dipersyaratkan jumlah suara anggota yang mendukungnya paling sedikit 1/3 dari keseluruhan anggota MPR. Untuk menjamin perubahan tidak dilakukan secara serampangan, pengajuan usul perubahan pasal-pasal UUD 1945 harus diajukan secara tertulis, bukan melalui pernyataan lisan.

Oleh sebab itu penunjukan secara jelas bagian tertentu yang diusulkan untuk diubah paling tidak mampu mengurangi kekurang cermatan MPR dalam mengubah UUD 1945. Perlunya usul perubahan pasalpasal UUS 1945 yang dilengkapi dengan alasan tertulis adalah berperan meminimalisir resiko politik MPR yang ingin mengubah pasalpasal UUD 1945 tanpa arah dan konsep yang jelas. Usul yang diajukan secara tertulis yang disertai dengan alasan logis dan rasional mengenai perubahan pasal-pasal UUD 1945 oleh anggota MPR baru sebatas kehendak politis yang harus mendapat dukungan kekuatan politik supaya sah secara konstitusional. 
Oleh karena itu, dukungan politik untuk mengubah pasal-pasal UUD 1945 ditentukan sekurang-kurangnya 2/3 dari jumlah anggota MPR. Tetapi putusan perubahan pasal-pasal UUD 1945 baru dinyatakan konstitusional apabila dilakukan dengan persetujuan suara mayoritas mutak, yaitu $50 \%+1$ anggota dari seluruh anggota MPR.

Menariknya UUD 1945 melalui salah satu ketentuannya telah merestriksi MPR dalam menjalankan kewenangannya untuk mengubah UUD 1945. Secara garis besarnya terdapat dua ayat dalam Pasal 37 UUD 1945 yang mempersempit ruang gerak MPR untuk mengubah UUD 1945. Pertama, secara implisit, MPR tidak berwenang mengotak-atik Pembukaan UUD 1945. Pembatasan konstitusional itu tersirat dari ketentuan Pasal 37 Ayat (1) UUD 1945 yang menegaskan, bahwa MPR hanya berwenang mengubah pasal-pasal UUD 1945. Artinya Pembukaan UUD 1945 tidak termasuk objek perubahan konstitusi. Disadari atau tidak, MPR melalui perubahan ke 4 (empat) UUD 1945 telah memisahkan kedudukan hukum antara Pembukaan UUD 1945 dengan pasal-pasalnya (Santika, 2020).

Sehingga kedudukan Pancasila itu sendiri sebenarnya berada di luar UUD 1945, maka MPR tidak berhak untuk mengubah bagian tertentu dari Pembukaan. Menurut Santika (2019) tujuan finalisasi Pancasila dalam UUD 1945 adalah daya dan upaya protektif untuk menangkal maupun mencegah bangkitnya kembali konflik ideologis di Indonesia. Sejarah pertikaian ideologis pada gilirannya berpengaruh signifikan terhadap persepsi rakyat Indonesia, bahwa mengganti atau mengubah Pancasila tidak ada bedanya dengan membubarkan Negara Proklamasi (Santika, 2019).
Kedua, secara eksplisit, bahwa MPR dilarang mengubah bentuk Negara Kesatuan Republik Indonesia. Pembatasan kewenangan MPR untuk tidak mengubah bentuk Negara Kesatuan Republik Indonesia tertuang jelas dalam Pasal 37 Ayat (5) UUD 1945. Bentuk negara kesatuan dinyatakan dengan tegas sebagai substansi yang tidak dapat diubah (non-amendable) (Sekretariat MPR RI, 2012).

Selain berwenang mengubah dan menetapkan UUD 1945, menurut Pasal 3 Ayat (2) UUD 1945 MPR juga bertugas melantik Presiden dan/atau Wakil Presiden. Pasal 3 Ayat (2) UUD 1945 merupakan tugas MPR melantik Presiden dan/atau Wakil Presiden, baik dalam kondisi normal maupun tidak normal. Tugas MPR melantik Presiden dan/atau Wakil Presiden secara rutin atau periodik lima tahunan sebagai hasil pemilu menurut Pasal 6 Ayat (1) UUD 1945 ialah pengangkatan sumpah atau janji yang berlangsung dalam situasi normal.

Sedangkan Pasal 8 Ayat (1), (2), dan (3) UUD 1945 adalah pelantikan Presiden dan/atau Wakil Presiden yang dilaksanakan MPR secara tidak normal (luar biasa). Hal itu terjadi karena faktor keterpaksaan yang menyebabkan MPR tidak ada pilihan selain melangsungkan pelantikan Presiden dan/atau Wakil Presiden, meskipun itu diluar kalender ketatanegaraan yang semestinya. Oleh sebab itu, pelantikan Presiden dan/atau Wakil Presiden berdasarkan Pasal 8 Ayat (1), (2), dan (3) UUD 1945, dapat dikatagorikan sebagai tugas MPR yang bersifat tidak biasa (istimewa).

Di samping dua kewenangan MPR yang telah dibahas sebelumnya, bahwa MPR sesungguhnya masih mempunyai satu kewenangan 
konstitusional lain, yaitu memakzulkan Presiden dan/atau Wakil Presiden menurut UUD 1945. Pasal 3 Ayat (3) UUD 1945 telah memformalisasi wewenang MPR untuk memberhentikan Presiden dan/atau Wakil Presiden dalam masa jabatannya menurut undang-undang dasar.

Pasal 7A dan Pasal 7B UUD
1945 yang mengatur prosedur
impeachment Presiden dan/atau Wakil Presiden pada intinya mengandung pengertian, bahwa MPR hanya dapat memberhentikan Presiden dan/atau Wakil Presiden bila benar-benar terbukti telah melakukan pelanggaran hukum, serta pelanggaran lainnya yang ditentukan secara limitatif dalam UUD 1945. Di samping karena adanya alasan lainnya bahwa Presiden dan/atau Wakil Presiden tidak lagi memenuhi syarat sebagai Presiden dan/atau Wakil Presiden.

Menurut mekanisme pemakzulan Presiden dan/atau Wakil Presiden yang diformalisasi dalam Pasal 7A dan 7B UUD 1945, dapat disimpulkan, bahwa kewenangan pemberhentian Presiden dan/atau Wakil Presiden berada di tangan MPR. Namun sebelum MPR menjalankan kewenangannya tersebut haruslah didahului dengan adanya pendapat DPR yang memuat tuduhan atau dakwaan pelanggaran Presiden dan/atau Wakil Presiden berdasarkan UUD 1945. Sedangkan pendapat DPR tersebut harus diajukan terlebih dahulu kepada MK untuk diperiksa dan diputus seadil-adilnya. Jika MK memutuskan pendapat DPR menyangkut dugaan pelanggaran yang dilakukan Presiden dan/atau Wakil Presiden benar-benar terbukti berdasarkan UUD 1945, maka barulah DPR melanjutkan usulnya itu kepada MPR. MPR wajib memutuskan secara final dan mengikat (final and binding) menyangkut nasib Presiden dan/atau Wakil Presiden, apakah akan memberhentikannya atau tidak dari jabatannya. Putusan itupun baru boleh diambil MPR setelah Presiden dan/atau Wakil Presiden diberikan kesempatan untuk menyampaikan penjelasannya.

Tetapi bila diperhatikan lagi Pasal 7B Ayat (1) UUD 1945 yang di dalamnya terpampang kalimat "hanya dengan terlebih dahulu mengajukan permintaan", maka peneliti mengambil kesimpulan, bahwa MPR tidak dapat memberhentikan Presiden dan/atau Wakil Presiden apabila pendapat DPR ditolak MK (Santika, 2019)

\section{PENUTUP}

Pasal 1 Ayat (2) UUD 1945 sebelum diubah menempatkan MPR sebagai lembaga negara super power yang menjadi lokus kedaulatan rakyat Indonesia. Checks and balances dalam sistem ketatanegaraan pun tidak dapat berjalan dengan optimal. Kemudian Pasal 1 Ayat (2) UUD 1945 hasil perubahan menurunkan derajat MPR. Secara konstitusional pasca perubahan Pasal 1 Ayat (2) UUD 1945 kedudukan MPR dengan lembaga negara lainnya dalam UUD 1945 adalah sejajar. Perubahan UUD 1945 ternyata juga merombak susunan keanggotaan MPR. Sebelum Pasal 2 Ayat (1) UUD 1945 diubah, MPR terdiri atas anggota-angota DPR, UtusanUtusan Golongan, dan Daerah. Sebagian besar keanggotaannya tidak diseleksi dan dipilih melalui pemilu yang demokratis, melainkan diangkat oleh Presiden. Setelah diubah, Pasal 2 Ayat (1) UUD 1945, MPR terdiri atas anggota DPR dan anggota DPD. Setelah reformasi konstitusi, pelembagaan pemilu dalam menentukan keanggotaan MPR 
adalah bersifat imperatif. Menurut Pasal 3 Ayat (1) UUD 1945 sebelum diubah, MPR berwenang menetapkan UUD dan garis-garis besar haluan negara. Hal itu pernah menjadi polemi kemudia Pasal 3 Ayat (1) UUD 1945 diubah sehingga semakin meneguhkan kedudukan MPR dalam mengubah dan menetapkan UUD. Menariknya lagi tercantum pembatasan kewenangan MPR dalam mengubah UUD 1945. Dalam mengubah UUD 1945, secara implisit MPR tidak dapat mengotak-atik Pembukaan UUD 1945. Di samping itu, secara eksplisit MPR dilarang mengubah bentuk Negara Kesatuan Republik Indonesia. Menurut Pasal 8 UUD 1945 hasil perubahan, MPR berwenang melantik Presiden dan/atau Wakil Presiden. Kewenangan MPR itu dapat dilaksanakan baik secara normal maupun tidak normal (istimewa).

\section{DAFTAR PUSTAKA}

Asmara, Galang. (2015). Penguatan Kelembagaan MPR Dalam Sistem Ketatanegaraan Republik Indonesia. Hasanuddin Law Review. 1 (3), 357-370. http://dx.doi.org/10.20956/halrev .v1i3.115.

Isra, Saldi. (2010). Pergeseran Fungsi Legislasi: Menguatnya Model Legislasi Parlementer Dalam Sistem Presidensial Indonesia. Jakarta: PT RajaGrafindo Persada.

MPR RI. (2012). Empat Pilar Kehidupan Berbangsa Dan Bernegara. Jakarta: Sekretariat Jenderal MPR RI.

Oktava, M. Sauki. (2017). Eksistensi Ketetapan MPR/S Dalam
Hierarki Peraturan PerundangUndangan Di Indonesia. Jurnal IUS. 5 (1). 120-142. http://dx.doi.org/10.29303/ius.v5i 1.434 .

Sekretariat Jenderal MPR RI. (2011). Panduan Pemasyarakatan Undang-Undang Dasar Negara Republik Indonesia Tahun 1945: Sesuai dengan Urutan Bab, Pasal dan Ayat. Jakarta: Sekretariat MPR RI.

Rannie, Mahesa. Kedudukan Majelis Permusyawaratan Rakyat Dalam Struktur Ketatanegaraan Indonesia Pasca Amandemen UUD 1945. Simbur Cahaya. 24 (2), 4844-4856. http://dx.doi.org/10.28946/sc.v24 i2\%20Mei\%202017.59

Rohmat, Ah Mujib. (2016). Kedudukan Kewenangan Majelis Permusyawaratan Rakyat Dalam Era Reformasi. Jurnal Pembaharuan Hukum. 3 (2), 181-190.

http://dx.doi.org/10.26532/jph.v3i 2.1408

Santika, I. G. N. (2019). Presidensialisme Dan Problematika Mekanisme Impeachment Presiden Dan/Atau Wakil Presiden Berdasarkan UUD 1945 Pasca Perubahan (Perspektif Pergulatan Hukum Dan Politik). Jurnal IImiah IImu Sosial. 5 (1), 23-34.

http://dx.doi.org/10.23887/jiis.v5i 1.18777

Santika, I. G. N., Sujana, G., \& Winaya., M. A. (2019). Membangun Kesadaran Integratif Bangsa Indonesia 
Melalui Refleksi Perjalanan Historis Pancasila Dalam Perspektif Konflik Ideologis. Jurnal Etika Demokrasi (JED). 4 (2), 89-98. https://doi.org/10.26618/jed.v4i2. $\underline{2391}$

Santika, I. G. N., Purnawijaya, I. P. E., \& Sujana, I. G. (2019). Membangun Kualitas Sistem Politik Demokrasi Indonesia Melalui Pemilu Dalam Perspektif Integrasi Bangsa Dengan Berorientasikan Roh Ideologi Pancasila. Seminar Nasional 1 Hukum dan Kewarganegaraan. 1 (1), 74-85.

Santika, I. G. N., Rindawan, I. K., \& Sujana, I. G. (2019). Memperkuat Pancasila Melalui Pergub No. 79 Tahun 2018 Dalam Menanggulangi Pengikisan Budaya Di Era Revolusi Industri 4.0. Prosiding Seminar Nasional Inobali 2019, 79, 981-990

Santika, I Gusti Ngurah. 2017. Kepala Sekolah Dalam Konsep Kepemimpinan Pendidikan: Suatu Kajian Teoritis. Widya Accarya. 7 (1).

Santika, I. G. N. (2020). Menelisik Akar Kegaduhan Bangsa Indonesia Pasca Disetujuinya Hasil Revisi UU KPK Dalam Perspektif Pancasila. Jurnal IImiah IImu Sosial. 6 (1), 6-36. http://dx.doi.org/10.23887/iiis.v6i $\underline{1.25001}$

Santika, I. G. N. (2020). Menggali dan Menemukan Roh Pancasila
Secara Kontekstual. Jawa Tengah: Lakeisha.

Santika, I. G. N. (2020). Optimalisasi Peran Keluarga Dalam Menghadapi Persoalan Covid19: Sebuah Kajian Literatur. Jurnal IImiah IImu Sosial. 6 (2), 127-137.

http://dx.doi.org/10.23887/jiis.v6i $\underline{2.28437}$

Santika, I. G. N. (2021). Pendidikan Kewarganegaraan (Studi Komparatif Konstitusi Dengan UUD 1945). Jawa Tengah: Lakeisha.

Ubaidillah, Lutfian. (2017). Politik Hukum Kedudukan Majelis Permusyawaratan Rakyat Dalam Sistem Ketatanegaraan Indonesia Berdasarkan UndangUndang Dasar Negara Republik Indonesia 1945. Fairness and Justice Jurnal IImiah IImu Hukum. 15 (1), 56-69. https://doi.org/10.32528/faj.v15i1 .2078

Widayati, Absori, \& Aidul Fitriciada Azhari. (2014). Rekonstruksi Kedudukan Ketetapan MPR Dalam Sistem Ketatanegaraan Indonesia. Jurnal Media Hukum. 21 (2), 265-278.

Yani, Ahmmad. (2018). Analisis Kontruksi Struktural dan Kewenangan DPR dalam Fungsi Legislasi Berdasarkan Undang-Undang Dasar 1945. Jurnal Konstitusi. 15 (2), 348368. 